\title{
Soft Skill Development in Vocational Schools to Produce Competent Graduates Needed by the B usiness/Industry World
}

\author{
Rismaja Putra \\ Industrial Management Engineering Study Program, Indonesian Academy of Engineering, Cut Mutia, \\ Indonesia \\ Putra.jissho@yahoo.com
}

\begin{abstract}
Companies looking for employees, the most important thing is not hard skills, but soft skills, this is because 80 percent of people are successful because of soft skills. In this case, students from the State Vocational School (SMK) in Banda Aceh need to develop good soft skills since grade X. Special attention and synergy between school principals as leaders, teachers and school officers as teachers and mentors need to be done properly. Implementation in a consistent and integrated manner in a sustainable manner will produce graduates and human resources who are superior and skilled, and graduates who are able to meet the needs of the business world and industry.
\end{abstract}

Keywords: soft skill; competent; development

\section{Introduction}

The diversity of understanding and all of their implications regarding technological and vocational education in Indonesia appears as a product of the history of development. In the early 1950 s to 1984 , technology and vocational education were linked to schools that produced graduates to fill the semi-skilled workforce at the junior secondary level, while SMK produced graduates needed for intermediate technicians/interpreter.

The types of techno; ogi and vocational schools are very diverse, such as group programs for agriculture, technology and industry, tourism and community welfare, business management, arts and crafts, and maritime affairs and information technology.

In order to better understand vocational education, it is necessary to study the underlying characteristics and concepts, including:

1. Basic philosophy of vocational education

2. Assumption of students

3. The social context of vocational education

4. Economic dimension of vocational education

5. Vocational education and employment

The characteristics of vocational education are aspects of educational orientation, justification for existence, curriculum focus, success criteria, sensitivity to community development, logistics supplies, and relations with the business community.

Technical expertise alone is not sufficient to equip a person to become a quality human being for himself, his family, community and society. Interpersonal skills are the perfect complement when one communicates with others, and makes use of their technical skills to the benefit of many people.

As new skills or technical skills continue to emerge, this is not the case with interpersonal skills. In fact, the existence of information and communication technology tools seems to eliminate the need for interpersonal skills or in this case soft skills.

Basically, softskill is a combination of people skills, social skills, communication skills, character, attitudes, career attributes, social intelligence, and Emotional Intelligence 
Quotien (EQ) which allows people to observe various things in their environment, making it easier for them to work with other people., and performs well.

\section{Review of Literatures}

The Collin English Dictionary defines the term "soft skills" as the expected quality of work, regardless of whatever work is done, soft skills include common sense, the ability to deal with people, and a positive flexible attitude. According to the research results, $75 \%$ of job success is determined by soft skills and only $25 \%$ is determined by hard skills (Abbas, Abdul Kadir, \& Ghani Azmie, 2013).

Why does the achievement of national ideals not move forward rapidly, even if there are signs of a slowdown in fundamental and strategic fields? Many factors influence, one of which is the most critical and fundamental factor of human resources (HR). Not in terms of quantity, but in terms of quality. In terms of population, Indonesia is the largest among the countries in the ASEAN region, but in terms of quality, our nation is relatively weak when compared to Malasyia, Singapore, Thailand, and Vietnam. whereas in order to drive progress in a sustainable manner, it is absolutely necessary to have the support of qualified and reliable human resources, who have good discipline, ethos and ethics.

Competence for humans is a tool for living, a good and right life, a quality and prosperous life, and one that is able to share with others. Any occupation requires competence. To acquire competence, one must learn. learning is a process of developing human capacity. There are many ways to learn, it can be done formally through formal educational institutions, it can be non-formally through training institutions, it can be informally through family and self-taught. Thus the opportunity to develop competences is open as wide as an ocean for anyone who wants to learn, without being limited by space or method. Likewise, of course it is very easy to do it for formal education, especially at the Vocational Middle School level of education, if it is applied consistently,

Competence according to the Regulation of the Minister of Education and Culture of the Republic of Indonesia Number 70 of 2013 "Curriculum 2013 aims to prepare Indonesian people to be an affective method and able to contribute to the life of society, nation, state and world civilization." Education and curriculums are connected and share a relationship in which both of them are enhanced (Campbell-Phillips, 2020). Imelda (2019) stated that 2013 curriculum hopes are still experiencing many obstacles from both teachers and Students. Assessment in the 2013 curriculum must refer to authentic assessment which includes three areas of assessment, namely affective, cognitive, and psychomotor (Hutapea, 2020).

The general meaning of competence is human ability. Semantically, the meaning in the large Indonesian dictionary, competence is the ability and ability to determine or decide something. Advanced Learners of English Dictionery describes competence in several meanings: competent (of person) having ability, power, authority, skill, knowledge, etc (to do what is needed). This means having the ability, power, authority, skills, knowledge, etc. (to do what is necessary). 


\section{Research Methods}

The research method used in this research is descriptive method, namely problem solving procedures that are investigated by describing the subject or object at the present time based on the facts that appear or as they are. This method will reveal soft skills in pregraduation class XII students in relation to the needs of the business / industry which are carried out at SMK Negeri 2 in Banda Aceh, and 80 respondents from 8 majors, data collection techniques are carried out by interview, observation, documentation and a combination. Cooperation with the SMKN Special Job Exchange (BKK) in Aceh in December 2021.

Interview techniques are carried out by conducting interviews, direct writers with students, by asking several questions in a systematic and structured manner and contain questions concerning the business world / industry after graduation and general knowledge insight.

Observations are made directly, by making observations about performance, attitude, this is done by direct authors and other teachers from teachers at school.

Documentation data is carried out by requesting data from teachers, deputy principals of student affairs and school BKK, regarding attendance data, student activity data, and order and security data and information from school officials.

Documentation data is carried out by requesting data from teachers, deputy principals of student affairs and school BKK, regarding attendance data, student activity data, and order and security data and information from school officials.

\section{Results and Discussion}

Based on the analysis carried out in order for the results of this research to be achieved as expected, the following are things that were done to respondents regarding the items in soft skill research needed in the business world / industry as a potential workforce including the following:

1. Ability to communicate well and skillfully

Each respondent was given 5 minutes to introduce themselves and convey their wishes. here the interviewer assesses the articulation, body language, suitability in the presentation, the way of delivering to the interlocutor, and can communicate in two directions.

2. Have a neat and systematic way of working

In this case the respondent was given a task in accordance with their respective fields of expertise, the task given was a practical task with a length of 30 minutes, making an object, from the initial process of the preparation stage until the final result became an object. What is assessed is the speed of time, product quality, tidiness, cleanliness of the workplace, use of raw materials and stages of the work process.

3. Ability to lead a team (leadership)

In this case it is done in groups, and given several tasks that must be done, which is done in school as a group and individually by doing at home. One day after that, a group review was held concerning work indicators, job objectives and clear rules, while individuals could maintain their own identity, team work spirit, sense of responsibility and togetherness, were honest, open and able to communicate well. 
4. Having negotiation skills

This is done by creating a meeting room and discussion by dividing the groups, and given one case which can be resolved in 30 minutes. here the author assesses the ability to communicate, analyze, provide solutions, be careful in acting, as a good listener, committed and can control emotions.

5. Able to work in teams (team work)

Solid and effective cooperation is needed in an organization / company, what is done is to pay attention, a sense of togetherness and belonging, open communication. This is done individually and in groups

6. Discipline

Conducted in accordance with the rules that have been set in school, both in the form of general rules, rules at workshops, class rules, assignments, and personal rules. The data is taken from school and also done by the author himself

7. Responsible

The responsibility as a student is to study well and comply with the rules set by the school. Besides, students must also be able to respect other students and be able to cooperate with each other, maintain the good name of the school and maintain the stability of learning so that the knowledge taught by the teacher can be absorbed and understood well. Homework given by the teacher can be completed on time and correctly.

8. Able to work under pressure

Workloads and demands are commonplace in the world of work, in achieving company targets. And this will be felt when you have plunged into the world of professional work. This must be addressed properly, calmly, focus on the task at hand, can be done diligently and make it all a challenge in life to achieve success later. Here the author gives assignments above the deadline for studying hours and ordinary daily tasks with a short time of 1 day, and must be completed on time properly. The result Not all students can do it, only 65 percent can do well and on time. This is due to a lack of motivation and ethos.

9. Patient

Many people misinterpret the meaning of patience, generally they are synonymous with not doing something, or being silent. Patience must be interpreted in a positive way, be patient in doing something, persevere, and persevere, while praying and surrendering to the almighty God. At certain times, patience is very important in terms of work and daily life. For certain types of work, sometimes it requires patience in doing it, to get the results and targets that are achieved. In testing the value of patience, students are given tasks that are interesting, complicated, and take time according to their fields and majors. The results obtained are very few who are able to do as ordered under 50 percent. Boredom and an instant want to finish quickly are still deep in the mind and soul.

\section{Conclusion}

Today companies realize that employees who can synergize with the company are employees who are not only smart in hard skills, but also have good soft skills. Therefore, it is natural that in job vacancies advertisements, companies also include soft skill requirements as requirements that must be met by applicants. Inclusion of soft skills such as responsibility, patience, team work, and having a leadership spirit are examples of soft skills needed by companies. From the results of the analysis above that the soft skills of 
students at State Vocational High Schools in Banda Aceh are still lacking and incompetent and need development for fulfill the needs of the business / industrial world. In order to achieve this goal, the implementation is carried out since class $\mathrm{X}$ will be better, so that there is a balance between hard skills and soft skills.

\section{References}

Alphonse Bertillon's Shinoptic Table of Physiognomic by Trais (ca. 1909).

Al Falaq, A. (2015). Profesional Coach Certification Program. Coaching Indonesia http://plti.or.id/

Analyze Handswriting. https ://www.Wikiho.com/Analyze-Hand writing-(Graphology).

Aqib, Z., and Amrullah, A. (2016). Ensiklopedia Pendidikan \& Psikologi, Yogyakarta Andi.

Campbell-Phillips, S. (2020). Education and Curriculum Reform: The Impact They Have on Learning. Budapest International Research and Critics in Linguistics and Education (BirLE) Journal Vol 3 (2): 1074-1082.

Hutapea, L.S., Lubis, M., and Adisaputera, A. (2020). The Development of Authentic Assessment Instruments on Anecdotal Text Material for Class X Students of SMK Yapim Indrapura, Batu Bara Regency. Budapest International Research and Critics in Linguistics and Education (BirLE) Journal Vol 3 (4): 1814-1826.

Imelda, and Anzelina, D. (2019). Students' Activities in Learning with Problem Based Learning Based Module to Enhance Students' HOTS on the Subject of Straight Line Equations. Budapest International Research and Critics in Linguistics and Education (BirLE) Journal Vol 2 (4): 552-559.

Kumar, Vijaya. (2004). Body Laguage - Memahami Bahasa yang disampaikan Tubuh. Tugu Publisher.

Nevo, B. (1986). Scientific Aspects of Graphology : A Hanbook Sfringfield, IL. Thomas.

Sulianto, Feri. (2009) Sukses Berpresentasi- Memunculkan Karisma dan Gaya Orisinal Anda Jakarta: Elexmedia.

Sulianto, Feri. (2014) Rahasia Meraih Kesuksesan deangan Percepatan, Jakarta: Elexmedia Komputindo.

Sulianto, Feri. (2015). Teknik Meracik Warna. Yogyakarta: Penerbit, Andi.

Sulianto, Feri. (2018). Panduan Lengkap Pengembangan Soft Skill , Yogyakarta Andi.

Susilo, W. MBA. (2018). Strategi Menegakkan Mutu Pendidikan Tinggi Bebasis KKNI, Yogyakarta Andi. 